\title{
Media and the Geographies of Climate Justice: Indigenous Peoples, Nature and the Geopolitics of Climate Change
}

\author{
Anna Roosvall and Matthew Tegelberg \\ Stockholm University, Stockholm, Sweden, anna.roosvall@ims.su.se \\ York University, Toronto, Canada, mtegel@yorku.ca
}

\begin{abstract}
Climate change has universal, global implications and uneven, particular local effects. Examining how this complex phenomenon is understood in public discourse calls for the merging of theorizing on geography, justice, nature and the mediation of environmental protest. This article combines these strands to discuss relationships between peoples, places, politics, nature and the media in terms of climate justice. Empirical examples are drawn from interviews conducted with indigenous activists and observations of press events organized by indigenous groups during a U.N. climate summit. We argue that the "misframing" of indigenous peoples at international climate summits underlines the necessity to integrate the perspectives of marginalized, transnational groups and their growing demands for climate justice into future media research on climate change, and the need for a reframing of the mediation of climate change.
\end{abstract}

Keywords: climate justice, indigenous peoples, geography, media, climate change, international politics, nature, transnationalism, misframing, representation.

Acknowledgment: We wish to thank Professor Elisabeth Eide, Oslo University College, and Professor Risto Kunelius, University of Tampere for their inspiring work with the MediaClimate network. We would also like to thank the two anonymous reviewers for their encouraging and helpful feedback.

\section{Introduction}

The areas most exposed to acute climate change effects, such as melting ice, eroding coastlines, flooding, and drought tend to be geopolitically "remote" in relation to centres of power in media and politics. Moreover, they are often inhabited by indigenous peoples, living close to nature, with livelihoods intrinsically linked to shifts in the environment. ${ }^{1}$ This situation epitomizes Johnson's contention $(2009,297)$ that "Those who feel the most severe impacts may be in the worst position to address them-and may have done the least to create them". Indigenous peoples fall outside of the formal structure of international climate negotiations, like United Nations climate summits. If their voices and perspectives are heard at all, it is generally in alternative conference venues, at demonstrations or as witnesses in rare news stories from exposed areas (Roosvall and Tegelberg 2012). This article argues that media research on climate change must address this complex weave of people, nature, geography, politics and the media in terms of climate justice. Climate justice refers to views of climate change as an ethical issue, linking it to global equality, human rights and historical responsibility (de Onís 2012; Page 2006; Shepard and Corbin-Mark 2009, Shue 2014). The concept is hence particularly relevant to the case of indigenous peoples due to their histories of colonization,

\footnotetext{
${ }^{1}$ Indigenous peoples maintain historical continuity with pre-colonial societies; have strong ties to territories and natural resources; distinct social, political and economic systems; distinct languages, cultures and beliefs; and constitute non-dominant social groups who "resolve to maintain and reproduce their ancestral environments and systems as distinctive communities" (United Nations n.d.). When recognized as "indigenous" a group is often ascribed particular status within a nation. We pluralize indigenous peoples to underline the differences between indigenous groups (Smith 1999).
} 
political, and media marginalization (Meadows 2001; Alia 2011; Anderson and Robertson 2012).

During the 2009 U.N. climate summit in Copenhagen, calls for climate justice broke into mainstream media reporting (Ytterstad and Russell 2012). These calls must now be answered by research on how climate (in)justice is manifested in news media generally, and particularly in relation to indigenous peoples. Thus far media research on climate justice has been scarce, and has generally overlooked climate challenges faced by indigenous peoples and their growing demands for climate justice (Watt-Cloutier 2004). To address these gaps, this article grapples with two research questions: How can theorizing on the geography of justice, and more particularly climate justice, contribute to a framework for media research that meets challenges posed by the common and diverging impacts of climate change for indigenous peoples, and other transnational groups? And how, in turn, can this theorizing help to make sense of different understandings of these impacts?

The article is divided into two parts. The first part develops a theoretical framework that addresses transnational understandings of climate justice in a globalizing world characterized by unevenly distributed acute climate change effects. The theoretical discussion places emphasis on indigenous peoples since these groups often occupy traditional territories that span across vast geographical areas and transcend the boundaries of nation-states (Roosvall and Tegelberg 2012; 2013). The second part underpins these theoretical connections by examining interviews conducted with indigenous activists at the 2011 U.N. climate summit in Durban, South Africa. The empirical examples shed new light on how indigenous activists assess media coverage of climate change and illuminate the efforts indigenous groups make to communicate about climate change and justice. While the material we discuss is limited, we argue that the experiences of these indigenous groups highlight crucial challenges for media reporting on climate change; especially when it pertains to transnational groups and the corresponding tension between universal and particular rights. The article concludes by pointing to future directions for media research on climate justice which integrates the positions, perspectives and roles of transnational and politically marginalized groups like indigenous peoples.

\section{Scales of Geography and Justice}

Justice has traditionally been viewed as "the first virtue of social institutions", strongly connected to the nation-state and limited to its citizens (Rawls 1971). Later theorizing questions this geo-political limitation, adding geographical scales of justice to the traditional moral ones (Fraser 2008; Young 2011). The concept of scale (Fraser 2008) is relevant to a discussion of media and global climate change since it addresses extensions of space for instance in localities with differing experiences of climate change. These local dynamics contrast with U.N. climate summits where direct measures taken against climate change are international affairs that build on nation-state logics. In these settings, indigenous groups, who often experience climate impacts directly, appear as intra- and transnational anomalies. This divergence of scales demands further attention.

Theorizing on scales of geography and justice can contribute to media research on climate change. David Harvey integrates space, place and the environment into his theorizing on social processes and practical politics: "We need critical ways to think about how differences in ecological, economic, political and social conditions get produced [...] ways to evaluate the justice/injustice of the differences so produced" (Harvey 1996, 5). This statement resonates with the need for critical ways of thinking about how such differences are reproduced by the media. Harvey argues for a politics that recognizes how social and environmental justice can be traced at different scales $(1996,400)$. Echoing these sentiments, we argue that media research on climate change must examine the intersection of justice and geographical scales. This is crucial since most people learn about the universal and particular effects of climate change from the media (Sampei and Aoyagi-Usui 2009; Christensen et al. 2013), and in particular from reporting on events like international climate summits (Schäfer, Ivanova and Smith 2014, see also Eide and Kunelius 2012). 
Fraser stresses the need for a combination of scales of justice with geographical scales in the context of globalization. She contends that in the global era "misframing" (Fraser 2008, 114 ) is a major source of injustice. Misframing is a form of misrepresentation that occurs when some members of a constituency are denied access to just representation due to their geographical location in relation to the structure of a political arena. This problem arises, for instance, when a transnational source of injustice is addressed within a state-territorial frame that limits the horizon of justice to actors who reside upon and share membership in the political terrain of a modern state (Fraser 2008, 22-23). This misframing is precisely what indigenous groups, like the Sami, a transnational people spread across four nation-states (Norway, Sweden, Finland, and Russia), experience at U.N. climate summits where nation-states negotiate along territorial lines (Roosvall and Tegelberg 2012).

Concurrently representation and the risk of misframing is crucial for studying general news reporting and reporting on climate change in particular (Boykoff 2010; Carvalho 2007; Hall 1997; Nakamura 2012; Pietikäinen 2003). While political representation cannot be replaced by media representation, the connections between the two variants are strong. This connection has been identified and theorized in general media research (Hall 1997; Nakamura 2012), and in research on media and environmental justice (Takahashi and Meisner 2012). However, it is rarely acknowledged in media research on climate change (although see Roosvall and Tegelberg 2012; 2013).

The injustice of misframing can be remedied by granting the group in question political representation. Fraser characterizes this as one of three ways of approaching scales of justice (2008). The second is through a redistribution of means and the third through recognition. In the latter case, Fraser (2000) suggests recognition of status must concentrate on offering solutions to injustice, rather than the mere recognition of identity that was central to debates concerning cultural rights in the 1990s. She argues for recognition of the status of individual group members as "full partners in social interaction" (Fraser 2000, 113). Fraser $(2008,16)$ defines justice, in its basic form, as parity of participation. While recognition of identity remains a staple in journalism, often combined with an identity politics of difference, opportunities to focus on status in universal and particular terms have been revealed (Roosvall 2014). The crucial question is whether these opportunities are used: Are particular or universal injustices recognized in relation to the status of people? And if not, what are the obstacles? How are they connected to media and politics? And how are they connected to the structure of the COPs (a structure that is outlined below)? Gandy $(2013,225)$ contends that in struggles for environmental and climate justice answers to these questions of (mis)framing are crucial if we hope to identify "[...] an appropriate venue within which victims can be compensated for the harms they suffer, and where future harms can be limited by constraining the behaviours of those likely to be responsible."

Although a move from redistribution to recognition characterized the decline of the era of the Westphalian frame, all three approaches to injustice-redistribution, recognition and representation-remain necessary. Because it is impossible to isolate moral philosophy from capitalism, redistribution remains crucial in conjunction with post-Westphalian approaches to recognition and representation (Fraser 2000, 2009). Issues of misframing can furthermore be tackled by an affirmative or transformative politics of framing (Fraser 2008). The former is used to criticize a particular misframing, claiming that scales of geography and justice are interconnected in the wrong ways in a given context. The situation can arguably be remedied by creating new, autonomous nation-states. The latter approach is used to criticize nationstate framing logics as such. It aims to create fora where frames are shifted not only in particular instances, but transformed altogether. According to Fraser, this transformative politics of framing is exemplified by transnational activism at events like the World Social Forum, and in social justice oriented forms of indigenous and environmental activism (2008, 25; 2009). These movements attempt to re-define the subject of (in)justice by supplanting the national citizen as subject principle (Rawls 1971) with an "all-affected" or "all-subjected" principle (Fraser 2008; 2014). The new approach emphasizes that what defines a subject of justice is "joint subjection to a structure of governance, which sets the ground rules that govern their interaction" $(2008,65)$. This reconceptualization of the subject of justice is highly relevant to 
tensions inherent in the governance structure of U.N. climate summits and growing demands for climate justice.

When regarding representations of indigenous peoples in particular, geographical scales can be understood in two crucial ways. One concerns how diverging extensions of space matter (local-national-global) in political negotiations (Gandy, 2013). Another concerns how different views of nature might regard or disregard the limits of space (Roosvall and Tegelberg 2012). Social beings can never escape their embeddedness in the natural world (Harvey 1996, 26). Thus all political analysis must embrace this embeddedness, as we do in the following section.

\section{Divergent Visions of Nature}

Traditional western perspectives in science and economics understand nature as separate from humans. In dominant scientific narratives, flora and fauna reside in isolated categories while humanity is placed on a higher plane (Elliot 2006; Smith 1999). This ancient division between knowledge and life intensified during the Enlightenment with binary dualism playing a crucial role in the establishment of the scientific method (Apffel-Marglin 1998).

Another characteristic of the western paradigm is the conceptualization of nature as a commodity. James O'Connor (1997) links the commodification of nature to the spread of environmental injustice in what he calls the second contradiction of capitalism. In the capitalist economy, this second, ecological contradiction lies in an infinite cycle of production that draws on a finite supply of resources. The outcome is environmental degradation, which in turn, produces rising costs, diminishing profits, and eventually leads to economic crisis (O'Connor 1997; Foster 2002). Foster (2002) identifies a range of new social movements, including the environmental and climate justice movements, that have emerged to confront this ecological contradiction by calling for alternative forms of social organization. For these social movements, the failure of international governing bodies to respond to demands for climate justice stems from institutional structures that remain deeply ingrained in western conceptions of nature.

Binary dualism, like the one between humans and nature, influences how meaning is created in language and representation in general, and in news representation in particular where cultural stereotypes related to different peoples frequently oppose "western" to "the other" (Allan 1999; Hall 1997). Hence, the commodification of nature is also closely connected to mass mediation (Elliot 2006, 79), and thus relevant to discussions of media, representation and climate justice. The birth of mass mediation is often associated with the invention of the printing press, and the related breakthrough of nationalism in the $16^{\text {th }}$ century, also known as the birth of "print capitalism" (Anderson 1991). The drawing of "geographical boundaries across material natures" caused a "disjunction between the continuities of natural space" and the "discontinuity of national boundaries" (Elliot 2006, 85). Thereby cross-border phenomena are overlooked and environmental action obstructed. Consequently, the structural relationship between global capitalism and environmental injustice is routinely disregarded in dominant media framings of climate change, where the issue of climate change is largely de-politicized (Berglez and Olausson 2014).

In order to facilitate environmental action in an era of accelerating climate change impacts, we must reconsider dominant scientific, economic and media structures that reinforce this separation of humans and the natural world. This can occur in the form of questioning the naturalness of nature (Castree 2014) and the alleged border between nature and culture; or by challenging dominant economic structures that determine our connection with nature, as well as the alleged boundaries between humans and nature.

Scholars and activists have recently claimed that one method of responding to the acute global crisis of climate change is to acknowledge indigenous perspectives on the natural environment (Tipa 2009, Huntington 2013). Hulme (2009, 81-82) states that:

The value of the role of local environmental knowledge about climate has begun to be recognised. Such local knowledge-sometimes referred to as indigenous or traditional knowledge—has frequently been established over centuries of habitation. 
Hulme juxtaposes local, indigenous and traditional knowledge, unlike Guttorm (2011, 69-70) who distinguishes between local and indigenous knowledge. Sami knowledge, she claims, includes spiritual aspects and a holistic view of human-nature relations, whereas local knowledge does not. Indigenous and local knowledge in northern Sweden however shares the view that humans are part of nature, and should act accordingly (Guttorm 2011).

Traditional ecological knowledge (TEK) is a term that encompasses local and indigenous knowledge. Understandings of TEK vary with the world views of those who define it (McGregor 2004). Nonindigenous groups generally view TEK as a "body of knowledge" separate from the people who possess it. Conversely, indigenous peoples understand it as "[...] rooted in the spiritual health, culture, and language of the people and handed down from generation to generation [...] based on intimate knowledge of the land, water, snow and ice, weather and wildlife, and the relationships between all aspects of the environment" (McGregor 2004, 78). Differences between TEK and dominant western perspectives have not been sufficiently accounted for in research on the mediation of climate change (although see Roosvall and Tegelberg 2012, 2013). Our interviews attest to the importance of such an undertaking and further evidence the connection between prevailing views of nature, capitalism and climate justice.

\section{From Environmental to Climate Justice: Media, Citizens and Activism}

Before turning to closer examination of how climate justice theorizing can inform media research on climate change and indigenous peoples, it is important to consider an influential precursor to the climate justice movement. In the 1970s, the environmental justice movement emerged in the United States with a series of local acts of resistance, by poor people and people of color, to the zoning of hazardous waste landfill sites and other environmental threats to their communities (Bullard 1990). Initially confined to local issues and grassroots actors, the movement gathered momentum in the 1980s, culminating in the First National People of Color Environmental Leadership Summit in 1991. The movement's primary aim was to expose environmental racism; that is, policies and practices that negatively impact the environment in communities of color (Bullard 1990). In many national contexts, this became the catalyst for research that documented disproportionate concentrations of environmental threats in poor, racialized communities (Agyeman et al. 2003). Endres (2009) emphasizes that discursive aspects of such environmental colonialism require further study. Our interviews attempt to accomplish this by examining the assessments indigenous activists make of media reporting on climate change in their communities.

Pezzullo and Sandler (2007) explain that while human health has always been a concern for mainstream environmentalists, the environmental justice movement placed social inequalities at the top of its agenda. This represented a move away from nature conservation and the survival of endangered species toward the survival of humans, particularly poor and marginalized peoples identified as "other" (Harvey 1996, 286, 399; Pezzullo and Sandler 2007, 8-9). In placing emphasis on ending discrimination, the movement redefined the environment to encompass the totality of life conditions: air, water, wages, housing, education, health, equity, and justice (Harvey 1996, 391; Szasz 1994, 151). Media research on climate change must take this conceptualization of the environment into consideration, especially in the case of transnational indigenous peoples, as our analysis shall demonstrate.

This intimate relationship between humans and the natural world is a central theme in contributions by indigenous scholars to environmental justice research. The literature details specific cases of environmental injustice, such as toxic waste dumping, mineral extraction, and other hazardous industrial practices, disproportionately situated in proximity to indigenous communities. Scholars and activists describe the devastating impact these practices have had on local environments and ways of life (LaDuke, 1994; 1999; Westra 2007; Agyeman et al. 2009); evidencing that while marginalized in terms of geography, politics and mediation, indigenous groups are often centred regarding environmental injustice (Agyeman et al. 2009, 3). This research trajectory primarily focuses on demands for environmental justice 
in response to local environmental threats. However, as Harvey notes, all environmental movements fighting for particular causes have a choice to continue struggling locally or strive for a more universal politics, which "[...] involves a move from one level of abstractionattached to place - to quite different levels of abstraction capable of reaching across space in which communities could not be known in the same unmediated ways" (Harvey 1996, 399, emphasis added). Thus, by necessity, moving from local to global causes includes mediation. This calls for further investigation of the media's role in (mis)framing the issue of climate change.

Media studies of social activism have already begun merging with studies of environmental activism, particularly concerning digital media (Askanius and Uldham 2011; Davidsen 2011; Gavin and Marshall 2011; Segerberg and Bennett 2011). These works place environmental activism in the context of political activism and the media (Cottle and Lester 2011; Christensen 2011) or in the context of social justice (Sowards 2012). Some claim the climate justice movement made its breakthrough at the 2009 climate summit in Copenhagen (Ytterstad and Russell 2012), while others trace it back to 2000 (de Onís 2012). Ytterstad and Russell study "[...] the role of journalism in mediating the political goals and arguments of climate activists" (2012, 247). Like Askanius and Uldham (2011), they focus on the mediation of climate justice at U.N. climate summits. These studies make crucial contributions to understanding activism, media and climate justice in the context of the Global Justice Movement. We aim to add to this a theorization of how scales of justice relate to geographical scales more broadly, and particularly in relation to indigenous peoples.

There is a growing literature on media, indigenous peoples and environment/climate change (Björst 2012; Davidsen 2011; Takahashi and Meisner 2012; Roosvall and Tegelberg 2012, 2013). ${ }^{2}$ These works have generated insights on issues of citizenship, climate change and the media, and demonstrated the importance of more sufficient theorizing on media and climate justice. Theories that facilitate understanding of the tension between different extensions of space and how these relate to people; particularly as this pertains to justice, is an area surprisingly neglected thus far in mainstream media theory. ${ }^{3}$ Indigenous groups are citizens of nation-states, but often simultaneously constitute intra- or transnational groups, which are generally excluded from climate negotiations and poorly represented by governments. Research highlighting domestication and the nation-state as organizing principles in climate change reporting suggests that transnational perspectives are rare (Olausson 2014; Roosvall 2010). It is not in spite of this tendency but because of it that transnational perspectives should be considered in theories of media, climate change and justice.

Our previous research (Roosvall and Tegelberg 2012; 2013) indicates that indigenous peoples are "used" in media reporting to highlight the urgency of climate change, while their political perspectives are largely ignored. Kant characterized this tendency to treat people not as ends in themselves but as instruments as "radical evil" (1793/1998; see also Nussbaum 2013). Concurrently, indigenous knowledge about nature is represented as likeable but wrong when compared to western science (Roosvall and Tegelberg 2013). There is finally a specific injustice connected to indigenous peoples: as transnational groups they are misframed in nationally oriented media reporting (Roosvall and Tegelberg 2012, 2013) and in the summit area. This pattern may prove fatal; especially given concerns about the impact climate change is having on the colonized lands indigenous peoples inhabit.

\section{Studying Representations with the Represented}

During COP17 in Durban, we interviewed several activists from indigenous organizations who attended the summit as observers. The interviews took place outside the gates of the summit and in a general poster room located some distance from the official negotiations. We posed four questions that focused on media reporting, climate change and indigenous

\footnotetext{
2 There is also a growing literature on indigenous produced media (Hafsteinsson and Bredin 2011; Pietikäinen, 2008). Yet these studies seldom consider indigenous perspectives on climate change.

${ }^{3}$ While recent scholarship has linked climate justice and indigenous peoples, these studies lack a media focus (Cochrane 2014).
} 
peoples: 1) What do you think about media coverage of indigenous peoples and climate change? 2) Is there a difference between mainstream media and alternative media reporting on indigenous peoples and climate change? 3) Do you have an opinion on how media coverage could be improved? 4) Do you have advice for media researchers on how to approach these issues in future research? The questions do not explicitly address climate justice, but nevertheless generated responses that associate injustice with media coverage.

Methodologically, we draw on Kvale and Brinkmann's (2009) guide to interview research and Bryman's $(1996,46)$ position that open-ended interviews help to facilitate analysis of social matters from the perspectives of the actors involved. The interviews provide empirical evidence of the analytical applicability of a framework focused on the mediation of geographies of climate justice. Moreover, they provide a space for indigenous activists' perspectives on the mediation of climate change. Here we focus on six interviews conducted with representatives of organizations focused on indigenous issues during COP17: 1) Curtis Konek and Jordan Konek of the Inuit Youth Delegation, Arviat, Nunavut, Canada; 2) Vibeke Larsen, a Sami politician from Norway; 3) Raymond de Chavez of Tebtebba, an umbrella organization representing a network of indigenous groups from Southeast Asia, Latin America and Africa; 4) Tito Puanchir, President of the Confederation of Indigenous Nationalities of the Ecuadorian Amazon (CONFENIAE); 5) Tiina Kurvits of Many Strong Voices, an advocacy organization that promotes security and sustainability in coastal communities in the Arctic and in small island developing states; and 6) Francois Paulette, former Chief of Fort Smith First Nation, Northwest Territories, Canada. ${ }^{4}$

The interviews were transcribed verbatim and examined using critical discourse analysis (Laclau and Mouffe 1985; Winter-Jörgensen and Phillips 2002). In particular, we examine how the discourse of media, indigenous peoples and climate change can be understood as a nodal point-a privileged centre of discourse-to which other key concepts are connected. These central concepts are identified in the theoretical framework and considered according to frequency of appearance in the interviews. Geography, nature and politics appear as core concepts in the theoretical framework and in the narratives of the interviewees.

The interview analysis is further informed by three specific concepts from theorizing on the geography of justice: redistribution, recognition (of identity/status) and representation (Fraser 2008,2000 ). After identifying how these concepts manifest themselves in interviewees' accounts, we discuss climate justice and geography in relation to the mediation of nature and the mediation of politics. Our analysis concentrates on how interviewees view nature and politics in relation to climate change and the media, and how they practically relate to these subjects. Regarding justice, we identify: a) whether interviewees call for or relate to redistribution; b) whether recognition is evoked, whether interviewees feel the media recognize their perspectives and, if so, how (is identity or status acknowledged?); and c) whether interviewees advocate for and/or discuss political representation. Regarding geography, we identify statements concerning the geographies where interviewees live, as well as related geographies of climate change effects, and finally the geography of U.N. climate summits. Relating these geographies to one another and linking them to scales of justice demonstrates why the analytics of geography and justice must be intertwined.

To provide context for the interviews we engaged in basic participant observation (lorio 2011,13 ) of press events arranged by indigenous peoples. We attended any press conferences or events organized by an indigenous organization and publicized in the NGO tent. The next section recounts some of our observations from the summit halls and indigenous press events. The interview results are then presented in two thematic sub-sections.

\footnotetext{
${ }^{4}$ Interviews were conducted with representatives from all the indigenous organization present in the NGO tent.
} 


\section{Geographies of Climate Justice: Indigenous Perspectives on Nature, Politics and Mediation}

\subsection{At COP17 in Durban}

At U.N. COP summits nation-states with formal, political roles in the ongoing negotiations are referred to as "Parties". The "Parties" are divided into two main categories: Annex 1 Parties (industrialized countries) and Non-Annex 1 Parties (developing countries). These categories are determined according to a nation's expected level of commitment to global efforts to mitigate climate change. Organizations, with scales ranging from local to global, participate in the COP summits as "Observers". Such status provides a group with access to climate meetings, but no formal role in official decision-making. It is as part of this broad crosssection of civil society actors that indigenous peoples, and other transnational groups, are recognized within the COP process. Hence, when it comes to political representation at U.N. summits, indigenous participants occupy a position on the margins.

At COP17, a geography of (in)justice permeated the space of the summit. Indigenous organizations desiring to take part in the politics of the event resided on the margins in a large poster room located a considerable distance from the official proceedings, and accordingly from the majority of the media attention. In some cases, press events organized by indigenous groups were held in the main conference area. However, these events attracted very little media attention. At press conferences held by Tebtebba, the Indigenous Environmental Network and the Inuit Youth Delegation we sat in sparsely attended rooms where few questions were asked by the journalists present. During Tebtebba's press conference, indigenous representatives from four regions gave thorough presentations on climate change impacts that were met with silence. Human rights were central to the presentations, connecting the deliberations on climate change to issues of justice.

In the poster area, an Inuit Youth Delegation presentation attracted more attention. However, the audience mainly consisted of other NGOs and activists. The Inuit youth arrived late, because of a traffic jam, and hastily pulled traditional clothing over their jeans. A noteworthy gesture since it reinforces a statement made by a representative from International National Trusts Organization. When asked how media coverage of indigenous groups could be improved, his response was that: "wearing your indigenous...clothing actually says much more than talking about it" (Roosvall and Tegelberg 2012). Here emphasis is on the recognition of identity, rather than the status, of indigenous peoples. According to Fraser, such recognition will not sufficiently help a group maintain status on par with others (2000). The utterance moreover puts responsibility for media coverage on the people covered rather than on those producing the coverage. This is partially an issue of geography, in that we found media at the center and indigenous groups on the margins, of the COP structure, and in societies at large. The media marginalization of these groups, however, is not due to their dwelling on an absolute geographical margin but rather to their symbolic handling in dominant forms of media representation (Roosvall and Tegelberg 2012).

\subsection{Perspectives on Nature and the Media}

Interviewees rarely mention justice explicitly, but statements on the COP summits' failure to provide adequate spaces for their perspectives on nature indicate injustice. This is reflected in the sense of frustration many interviewees had with the summit as a place to express their views on nature and the general lack of attention to indigenous perspectives on nature in media discussions of climate change.

Several interviewees discuss traditional indigenous knowledge in opposition to western scientific perspectives on climate change. In an interview with the Inuit Youth Delegation, Curtis Konek says:

We're here to talk about our elders' perspective on climate change and hope that the government or the higher powers will listen to our elders' perspective. [...] they've been 
out on the land for so long and they see the changes and they know the changes and that is what the government should look at and study. [...] [the elders'] perspective on climate change because they know more than the scientists (personal communication, December $6,2011)$.

Konek views traditional indigenous knowledge as something that should be recognized as a catalyst for political action. He calls for recognition of the status of indigenous perspectives, rather than the recognition of identity and argues that governments should pay more attention to Inuit elders' intimate understandings of changes occurring in their natural surroundings. This emphasis on TEK demonstrates that the Inuit Youth Delegation went to Durban to generate awareness of perspectives on nature and climate change frequently neglected, underrepresented, or misunderstood.

Tito Puanchir, president of CONFENIAE, makes a related statement concerning the importance and uniqueness of Amazonian indigenous perspectives on nature and the environment: "We have an intimate relation with nature, with all living things. This is the reason why we care for the environment, why we give back with benevolence instead of destroying it, which we don't think is a good approach. How one manages the environment depends on how one understands it" (personal communication, December 5, 2011). Puanchir's statement emphasizes the importance of encompassing different understandings of nature in theories about climate change and the media. He contrasts indigenous perspectives on environmental conservation with the damaging impact agricultural projects and large scale mining are having in the Amazon basin. He fears that if these massive interventions continue nothing will remain for future generations. This has been the catalyst for Amazonian indigenous peoples to mobilize to defend their natural environments from further exploitation, calling for a redistribution of means instead.

Vibeke Larsen, a representative of the Sami parliament in Norway, underlines the importance of experiencing and knowing a place while discussing the impact of climate change on Sami reindeer herders in Norway:

Reindeer herders are in the front of the climate change and it will affect them very much, so if they [the media] could just try to take the climate change problems down to the south then they would see it has relevance for all the people that live in the north. [...] they [the media] and the people in the south don't understand what is happening here. They are not here, they don't understand (personal communication, December 6, 2011).

Larsen stresses that the ignorance of southern Norwegian media to what is happening in Sami communities stems from their geographic distance from the north ("They are not here, they don't understand"). This mirrors concerns raised by Agyeman et al. $(2009,3)$ about divisions between North and South in Canada where: "Northern peoples bear a disproportionate burden from economic development and natural resource extraction, since they do not benefit from the conveniences of mass industrial production as their southern neighbours do, yet experience deleterious changes to their economies, environments, and ways of life."

Larsen then provides an example of how misunderstanding and lack of dialogue between north and south can lead to conflict:

In the north, where the Sami people live, the Norwegian government are very fixated on green energy [...] windmills, wind energy. [...] It means that they have to take some reindeer inland to build this and you have to build roads into it and use lots of wires. So you have to take a lot of land. Then they [the windmills] come into conflict with Sami reindeer herding and you are in a conflict between climate and the traditional way to live... So it's a hard place for the Sami parliament because we want to be responsible for the society, we want to be responsible for our future, and at the same time we have to take care of our old culture and the reindeer herding (Ibid 2011). 
Larsen describes a conflict between Sami reindeer herders' traditional way of life and the green energy industry's infrastructure projects in northern Norway. Moreover, she represents conflicting ways of responding to changes in the natural environment. Climate friendly indigenous traditions collide with what is deemed a climate friendly energy source, which conflicts with traditional rights.

Conversely, Francois Paulette, a former chief and representative of Canada's Assembly of First Nations, describes how lands and cultures in the Canadian north are threatened by energy projects like the Athabasca tar sands: "they are increasing the tar sands output which will destroy more environment [...] the river, the people." He argues that people "need to have more of [...] an environmental conscience, more of a spiritual conscience about the land, the earth and us human beings" (personal communication, December 6, 2011). By focusing on nature and humans simultaneously, Paulette underlines spirituality, which connects TEK to climate justice.

Paulette and Larsen discuss energy projects from partly different angles. However, when they are asked about media coverage they both bring these up to exemplify a lack of understanding nature and ways of engaging with it. Interviewees express concern about the consequences associated with neglecting indigenous perspectives on the changes happening to their natural surroundings. Destructive western scientific and economic discourses and practices are contrasted with balanced relationships with the natural world. The examples illustrate the need for further analyses of media and climate change that combine indigenous knowledge with justice theories, subsequently merging into theories of climate justice. During the summit, these perspectives on nature and corresponding calls for recognition and redistribution largely fell on deaf ears, due to the international structure of the summit and the marginal position of these transnational actors; a clear instance of misframing (Fraser 2008).

Our final interview question sought advice on how to approach issues of media, indigenous peoples and climate change in future research. Vibeke Larsen's answer concisely summarized what many respondents expressed: "[...] media don't know the indigenous peoples...it seems like a lack of knowledge". Media researchers are advised to become more attentive to indigenous knowledge and share it with the public (personal communication, December 6, 2011; Roosvall and Tegelberg 2012). Tiina Kurvits called for further emphasis on how indigenous knowledge can be recognized in the media (personal communication, December 5, 2011). Knowledge about indigenous peoples, recognition of the status of indigenous knowledge about nature, and how these peoples and perspectives are represented by the media should thus be key areas of concern in future studies.

\subsection{Perspectives on Politics and the Media}

Several interviewees suggested they occupied a marginal position at the Durban summit in terms of mediation, commenting on their difficulty gaining access to journalists and other news media. Interviewees also discuss marginalization in terms of politics, expressing frustration with their status on the margins of the political structure of the negotiations. These instances of marginalization are connected, hence we argue theories of justice are needed in media studies. The following examples demonstrate moreover how scales of geography and justice intersect in the marginalization of indigenous peoples.

Tiina Kurvits (Many Strong Voices) highlighted the absence of Arctic indigenous peoples from mainstream media coverage of climate change effects in Polar regions. She explained that while there is coverage "in northern papers [in Canada] [...] in the mainstream media we're not seeing an awful lot [...] once in a while there might be something but it tends to focus on, say, the polar bears as opposed to the impact on the people that would be hunting bears or that are dependent on the wildlife on the land. I'm certainly not overwhelmed" (personal communication, December 5, 2011). The statement attests to the lack of perspectives on justice since the media focus lies on animals rather than humans. Kurvits elaborated on a strategy her organization uses to generate media exposure for indigenous and local perspectives on climate change. This is to plan press events that bring together indigenous political 
leaders from different effected regions: "The appeal there seems to be that when you have an Arctic person and somebody from a small island state the media does get interested [...] it's like, you know, what are you guys doing together?" (personal communication, December $5,2011)$. The comment underlines that for communication about acute situations in the Arctic and small island states to be effective, two leaders representing different cultures must be present. It is thus cultural differences that attract media attention, and thereby recognition of identity rather than status.

Kurvits addressed the lack of coverage in mainstream media in particular. She wished that activists knew better how to circulate their knowledge in the media: "The press releases [...] seem to get lost in a pile of all these other press releases" (personal communication, December 5, 2011). She expresses the need to know how they can get their stories out and what kinds of stories work best. A related question is whether it is constructive for social justice movements to approach mainstream media, or more constructive to focus on alternative media (Ekman 2011). While alternative media are crucial for any justice movement, penetrating mainstream media remains essential if the aim is to reach larger audiences. Interviewees struggled to gain mainstream media attention, rather than alternative media attention, even though mainstream media was viewed as industry biased and conservative: "most of the papers in the world are right wing conservative papers so they reflect the profile of industry and governments rather than the people" (Francois Paulette, personal communication, 6 December 2011).

Raymond de Chavez (Tebtebba) said alternative media were more interested in covering indigenous perspectives on climate change. In the mainstream media "you really have to find the hook, a good story line that will really catch the attention" (personal communication, December 5, 2011). de Chavez explained how Tebtebba used social media platforms like Twitter and Facebook to "raise the bar in terms of exposure to indigenous issues" (personal communication December 5, 2011). However, he expressed concern about getting media and media researchers to pay attention to indigenous perspectives. He criticized the media for marginalizing indigenous perspectives and encouraged media researchers to highlight the political role of indigenous groups at the summits, and to scrutinize the disparity between high media concentration at climate negotiations and the lack of media access for alternative groups (personal communication, December 5, 2011). Takahashi and Meisner $(2012,360)$ identify similar sentiments expressed by indigenous and environmental groups in Peru: "It is not possible from this study to determine whether the lack of media access by environmental groups and representatives of indigenous groups was due to a deliberate blockage from the media or their lack of organization and availability. Either way, their limited access could have affected the range of policy options." Evidently, the structure of the meetings and the lack of exposure to mainstream media functioned to marginalize these transnational groups and their perspectives on climate change. The range of policy options stemming from COP17 could have been wider if these structures had been more open to transnational indigenous perspectives.

At COP17, Norway was the only negotiating country with an indigenous representative in its official delegation. While this is a privileged position in relation to other indigenous groups, Sami representative Vibeke Larsen identified some drawbacks:

The consultation is sealed, secret until a report is there. So it's very hard for the Sami Parliament to show [...] where we stand because we have to seal it until the report is there. So we have the Sami society on our backs all the time, you are not doing enough for us and so on just because the process is like that [...] so when the government includes us indigenous people they also seal the process (personal communication, December 6, 2011).

Larsen experiences difficulty reconciling her official status in Norway's delegation with the responsibility of representing Sami interests. While Sami in Norway enjoy political representation, the conditions and limitations of this representation raise crucial questions. Returning to Fraser's framework for tackling injustice, we must ask whether this is just political repre- 
sentation or misframing through the imposition of state-territorial frames? And, regarding recognition, whether this is an issue of being recognized on par with others in terms of status? The same questions apply to media reporting: Does media reporting misframe, and what does media reporting recognize, identity or status?

\section{Conclusions}

This article elaborates on the politics of media representation, not only in terms of cultural stereotypes (Hall 1997) or ideologies connected to the representation of climate change (Carvalho 2007), but by framing the discussion as a matter of justice. A theoretical framework is introduced to tackle understandings of climate change impacts that transcend national boundaries, while still accounting for differences related to peoples and places.

The misframing that Fraser identifies as part of contemporary political structures permeates international climate negotiations. It occurs in media representations of U.N. climate summits, where transnational indigenous groups are misframed in various ways. Interviews and participant observation revealed that what was previously identified as misframing in media output (Roosvall and Tegelberg 2012; 2013) is built into the structure and conduct of media production during climate summits. These insights call for better inclusion of transnational groups who raise issues that are not only marginalized in media and politics, but in research as well.

The concept of misframing allows researchers to determine whether climate related issues are connected to relevant scales in media reporting. More particularly, theoretical focus on intersecting scales of geography and justice help enhance understanding of global, national, transnational and local scales that pertain to the politics and mediation of climate change. This occurs right down to the structuring of the summit and its localities. The summit and the mainstream media function according to the logic of nation-states, but transnational perspectives were evident in the activities and narratives of interviewees, who arguably attempt to reframe the issue of climate change by taking part in a transformative politics of framing (Fraser 2008). The organizations represented by the interviewees are not regulated by nation-states. On the contrary, transnationalism characterized the activities of groups like Tebtebba, Many Strong Voices, and CONFENIAE. Tebtebba arranged a transnational press conference featuring representatives from different parts of the global south who placed emphasis on status and highlighted human rights. Many Strong Voices underlined connections between the experiences of Arctic indigenous peoples and marginalized peoples from southern, small island nations. The examples highlight perspectives currently missing in media and international political structures and demonstrate the relevance of doing research with indigenous peoples to enhance understanding of transnational groups politically marginalized yet acutely exposed to climate change.

The experiences of indigenous groups show that people encounter multiple scales and that these scales are interrelated and synchronous. There are nation-state scales connected to the summits and to politics in general; global or planetary scales of possible implications and necessary adjustments to climate change; and intersecting transnational, local and regionally particular scales of uneven effects. Each of these scales are situated in politics and nature, making it essential to examine how boundaries and extensions of space are imagined in specific contexts. Nation-state scales currently dominate media representations of climate change. From the standpoint of justice, this calls for a transformative politics of framing climate change as a critical issue with indigenous groups positioned at the forefront. In order to tackle prevailing injustice, climate change must be reframed this way, in the media and elsewhere, to reflect its entanglement with multiple scales: as an issue simultaneously universal-in its implications for the entire world-and particular-in the uneven nature of its effects. Notions of universal status are often lacking in media output (Roosvall 2014), but could certainly be spelled out here in terms of equal human rights to life in non-threatening environments. From a perspective that acknowledges diverging geographical scales of justice (Fraser 2008) this recognition of universal status needs however to be combined with a recognition of particular status that addresses the particular effects climate change has in 
certain localities, for peoples with specific histories of colonization (political as well as politico-environmental) and corresponding cultural rights (particular identity). Prevailing injustice in terms of exposure to and political capacity to deal with acute climate change threats must at the same time in these areas be amended with particular redistribution of means and just political representation. Thus, in tackling global climate change, its uneven effects as well as the uneven access to resources, and how this is represented in the media, the operationalization and activation of all of Fraser's $(2008,2014)$ different remedies for injustice helps us understand and deal with the complexity of injustice in a globalizing world.

Without mentioning the word climate justice, interviewees repeatedly alluded to the concept in their responses; highlighting human rights, global implications, and a focus on humans rather than animals or the natural environment. Tina Kurvits criticized media for overusing polar bear images at the expense of Arctic people. Vibeke Larsen showed us, furthermore, what can be missed if indigenous perspectives are not considered; namely that a matter perceived by some as climate friendly, such as building windmills in reindeer herding territory, can be viewed by others as unjust.

This article begins to answer calls for research on climate justice by examining geographies of climate justice and integrating indigenous perspectives. We argue that such an approach is essential when dealing with a changing climate that affects the planet to varying degrees depending on geo-political location, and opportunities to tackle these effects that vary according to political representation, recognition and redistribution. Informed by these insights, our hope is that more research responds to calls by interviewees for: more emphasis on indigenous knowledge; greater attention to the politics of climate change in indigenous communities; and enhanced access to media at climate summits and with regard to the issue of climate change in general.

\section{References}

Agyeman, Julian, Peter Cole, Randolph Haluza-DeLay and Pat O'Riley, eds. 2009. Speaking For Ourselves: Environmental Justice in Canada. British Columbia: University of British Columbia Press.

Agyeman, Julian, Robert Bullard, and Bob Evans. 2003. Just Sustainabilities: Development in an Unequal World. Cambridge, MA: MIT Press.

Allan, Stuart. 1999. News Culture. Buckingham/Philadelphia: Open University Press.

Alia, Valerie. 1999. Un/covering the North: News, Media and Aboriginal People. British

Columbia: University of British Columbia Press.

Anderson, Benedict. 1991. Imagined Communities: Reflections on the Origins and Spread of Nationalism. London: Verso.

Anderson, Mark and Carmen Robertson. 2011. Seeing Red: A History of Natives in Canadian Newspapers. Manitoba: University of Manitoba Press.

Apffel-Marglin, Frédérique. 1998. The Spirit of Regeneration: Andean Culture Confronting Western Notions of Development. London: Zed Books.

Askanius, Tina and Julie Uldham. 2011. Online Social Media for Radical Politics: Climate Change Activism on YouTube. International Journal of Electronic Governance 4(1): 69-84.

Berglez, Peter and Ulrika Olausson. 2014. The Post-Political Condition of Climate Change: An Ideology Approach. Capitalism, Nature, Socialism, 25 (1): 54-71.

Bjørst, Lill. 2012. Climate Testimonies and Climate-Crisis Narratives: Inuit Delegated to Speak on Behalf of the Climate. Acta Borealia: A Nordic Journal of Circumpolar Societies 29 (1): 98-113.

Boykoff, Maxwell. 2010. Indian Media Representations of Climate Change in a Threatened Journalistic Ecosystem. Climatic Change 99: 17-25.

Bryman, Alan. 1996. Social Research Methods. London: Oxford University Press.

Bullard, Robert. 1990. Dumping in Dixie: Race, Class, and Environmental Quality. San Francisco: Westview Press.

Carvalho, Anabela. 2007. Ideological Cultures and Media Discourses on Scientific Knowledge: Rereading News on Climate Change. Public Understanding of Science 16: 233-243.

Castree, Noel. 2014. Making Sense of Nature. Abingdon/New York: Routledge.

Christensen, Christian. 2011. Twitter Revolutions? Addressing Social Media and Dissent. Communication Review 14 (3): 155-157. 
Christensen, Miyase, Annika E. Nilsson and Nina Wormbs. 2013. Changing Arctic-Changing World. In Media and the Politics of Arctic Climate Change: When the Ice Breaks, edited by Christensen, Miyase, Annika E. Nilsson and Nina Wormbs, 157-171. Basingstoke: Palgrave Macmillan.

Cochrane, Regina. 2014. Climate Change, Buen Vivir, and the Dialectic of Enlightenment: Toward a Feminist Critical Philosophy of Climate Justice. Hypathia 29 (3): 576-598.

Cottle, Simon and Libby Lester, eds. 2011. Transnational Protests and the Media. New York: Peter Lang.

Davidsen, Conny. 2011. Amazon Struggles in the Global Media Age: Framing and Discourses in Environmental Conflict. In Transnational Protests and the Media, edited by Simon Cottle and Libby Lester, 172-184. New York: Peter Lang.

De Onís, Katherine. 2012. "Looking both ways". Metaphor and the Rhetorical Alignment of Intersectional Climate Justice and Reproductive Justice Concerns. Environmental Communication: A Journal of Nature and Culture 6 (3): 308-327.

Eide, Elizabeth and Risto Kunelius, eds. 2012. Media Meets Climate: The Global Challenge for Journalism. Sweden: Nordicom.

Ekman, Mattias. 2011. Den globala rättviserörelsen i svenska medier [The Global Justice Movement in Swedish Media]. Stockholm: JMK.

Elliot, Nils Lindahl. 2006. Mediating Nature: Environmentalism and Modern Culture. Abingdon: Routledge.

Endres, Danielle. 2009. From Wasteland to Waste Site: The Role of Discourse in Nuclear Power's Environmental Injustices. Local Environment: The International Journal of Justice and Sustainability 14 (10): 917-937.

Foster, John Bellamy. 2002. Capitalism and Ecology: The Nature of the Contradiction. Monthly Review 54 (4). Accessed February 3, 2015. http://monthlyreview.org/2002/09/01/capitalism-and-ecology/.

Fraser, Nancy. 2014. Transnationalizing the Public Sphere: On the Legitimacy and Efficacy of Public Opinion in a Post-Westphalian World. In Transnationalizing the Public Sphere, edited by Kate Nash, 8-42. Cambridge: Polity.

Fraser, Nancy, Alfredo Gomez-Muller and Gabriel Rockhill. 2009. Global Justice and the Renewal of the Critical Theory Tradition. A Dialogue with Nancy Fraser. Eurozine. Accessed January 12, 2015. http://www.eurozine.com/articles/2009-04-21-fraser-en.html.

Fraser, Nancy. 2008. Scales of Justice: Reimagining Political Space in a Globalizing World. New York: Columbia University Press.

Fraser, Nancy. 2000. Rethinking Recognition: Overcoming Displacement and Reification in Cultural Politics. New Left Review 3: 107-120.

Gandy, Oscar. 2013. Wedging Equity and Environmental Justice into the Discourse on Sustainability. Triple C: Communication, Capitalism \& Critique 11 (1): 221-236.

Gavin, Neil and Tom Marshall. 2011. Climate Change and International protest at Copenhagen: Reflections on British Television and the Web. In Transnational Protests and the Media, edited by Simon Cottle and Libby Lester, 197-212. New York: Peter Lang.

Guttorm, Gunvor. 2011. Árbediehtu (Sami Traditional Knowledge) as a Concept and in Practice. In Working with Traditional Knowledge: Communities, Institutions, Information Systems, Law and Ethics, edited by Jelena Porsanger and Gunvor Guttorm, 59-76. Sámi Allaskuvla / Sami University College.

Hafsteinsson, Sigurjón and Marian Bredin. 2011. Indigenous Screen Cultures in Canada. Manitoba: University of Manitoba Press.

Hall, Stuart. 1997. Representation: Cultural Representations and Signifying Practices. London: Sage.

Harvey, David. 1997. Justice, Nature and the Geography of Difference. Oxford: Blackwell.

Hulme, Mike. 2009. Why We Disagree About Climate Change. Cambridge: Cambridge University Press.

Huntington, Henry P. 2013. A Question of Scale: Local versus Pan-Arctic Impacts from Sea-Ice Change. In Media and the Politics of Arctic Climate Change: When the Ice Breaks, edited by, Miyase Christensen, Annika E. Nilsson and Nina Wormbs, 114-127. Basingstoke: Palgrave Macmillan.

Iorio, Sharon Hartin. 2011. Qualitative Method Journalism. In Qualitative Research in Journalism: Taking it to the Streets, edited by Sharon Hartin Iorio, 3-20. New York: Routledge.

Johnson, Seth. 2009. Climate Change and Global Justice: Crafting Fair Solutions for Nations and Peoples. Harvard Environmental Law Review 33 (2): 297-301. 
Kant, Immanuel. 1793/1998. Religion within the Boundaries of Mere Reason. New York and Cambridge: Cambridge University Press.

Kvale, Steinar and Svend Brinkman. 2009. InterViews: Learning the Craft of Qualitative Research Interviewing. London: Sage.

Laclau, Ernesto and Chantal Mouffe. 1985. Hegemony and Socialist Strategy: Towards a Radical Democratic Politics. New York: Verso.

LaDuke, Winona. 1994. Traditional Ecological Knowledge and Environmental Futures. Colorado International Environmental Law and Policy 5: 127-148.

LaDuke, Winona. 1999. All Our Relations: Native Struggles for Land and Life. Cambridge, MA: South End Press.

McGregor, Deborah. 2004. Traditional Ecological Knowledge and Sustainable Development: Towards Coexistence. In In the Way of Development: Indigenous Peoples, Life Projects and Globalization, edited by Mario Blaser, Harvey A. Feit and Glenn McRae, 72-91. London: Zed Books.

Meadows, Michael. 2001. Voices in the Wilderness: Images of Aboriginal People in the Media. London: Greenwood Press.

Nakamura, Lisa. 2010. Race and Identity in Digital Media. In Mass Media and Society, edited by James Curran, 336-347. New York: Bloomsbury Academic.

Nussbaum, Martha, C. 2013. Political Emotions: Why Love Matters for Justice. Cambridge, MA/London: Harvard University Press.

O'Connor, James. 1997. Natural Causes: Essays in Ecological Marxism New York: The Guilford Press.

Olausson, Ulrika. 2014. The Diversified Nature of "Domesticated" News Discourse: The Case of Climate Change in National News Media. Journalism Studies 15 (6): 711-725.

Owen, David. 2014. Dilemmas of Inclusion. The All-Effected Principle, The All-Subjected Principle, and Transnational Public Spheres", in Transnationalizing the Public Sphere, edited by Kate Nash, 112-128. Cambridge: Polity.

Page, Edward A. 2006. Climate Change, Justice and Future Generations. Cheltenham UK: Edward Elgar Publishing.

Pezzullo, Phaedra and Ronald Sandler. 2007. Environmental Justice and Environmentalism: The Social Justice Challenge to the Environmental Movement. Cambridge, MA: MIT Press.

Phillips, Louise, Anabela Carvalho and Julie Doyle, eds. 2012. Citizen Voices: Performing Public Participation in Science and Environmental Communication. Bristol, UK: Intellect.

Pietikäinen, Sari. 2003. Indigenous Identity in Print: Representations of the Sami in News Discourse. Discourse and Society 14 (5): 581-609.

Pietikäinen, Sari. 2008. Sami in the Media: Questions of Language Vitality and Cultural Hybridization. Journal of Multicultural Discourses 3 (1): 22-35.

Rawls, John. 1971. A Theory of Justice. Harvard: Harvard University Press.

Roosvall, Anna. 2014. The Identity Politics of World News: Oneness, Particularity, Identity and Status in Online Slideshows. International Journal of Cultural Studies 17 (1): 55-74.

Roosvall, Anna and Matthew Tegelberg. 2013. Framing Climate Change and Indigenous Peoples: Intermediaries of Urgency, Spirituality and De-nationalization. International Communication Gazette 75 (1): 392-409.

Roosvall, Anna and Matthew Tegelberg. 2012. Misframing the Messenger: Scales of Justice, Traditional Ecological Knowledge and Media Coverage of Indigenous Peoples and Climate Change. In Media Meets Climate: The Global Challenge for Journalism, edited by Elisabeth Eide and Risto Kunelius, 297-312. Nordicom: Sweden.

Roosvall, A. 2010. Sweden: Between Domestication and Glocalisation. In Global Climate, Local Journalisms: A Transnational Study of How Media Make Sense of Climate Summits, edited by Elisabeth Eide, Risto Kunelius and Ville Kumpu, 309-324. Bochum: Projekt Verlag.

Sampei, Yuki and Midori Aoyagi-Usui. 2009. Mass Media Coverage, Its Influence on Public Awareness of Climate Change Issues, and Implications for Japan's National Campaign to Reduce Greenhouse Gas Emissions. Global Environmental Change 9 (1): 203-212.

Schäfer, Mike, Anna Ivanova and Andreas Schmidt. 2014. What Drives Media Attention for Climate Change? Explaining Issue Attention in Australian, German and Indian Print Media from 1996 to 2010. International Communication Gazette 76 (2): 152-176.

Segerberg, Alexandra and Lance Bennett. 2011. Social Media and the Organization of 
Collective Action: Using Twitter to Explore the Ecologies of Two Climate Change

Protests. Communication Review 14: 197-215.

Shepard, Peggy and Cecil Corbin-Mark. 2009. Climate Justice. Environmental Justice 2 (4): 163-166.

Shue, Henry. 2014. Climate Justice: Vulnerability and Protection. Oxford: Oxford University Press.

Smith, Linda T. 1999. Decolonizing Methodologies: Research and Indigenous Peoples. London: Zed Books.

Sowards, Sonia K. 2012. Environmental Justice in International Contexts: Understanding Intersections for Social Justice in the Twenty-first Century. Environmental Communication: A Journal of Nature and Culture 6 (3): 285-289.

Szasz, Andrew. 1994. Ecopopulism: Toxic Waste and the Movement for Environmental Justice. Minneapolis: University of Minnesota Press.

Takahashi, Bruno and Mark Meisner. 2012. Environmental Discourses and Discourse Coalitions in the Reconfiguring of Peru's Environmental Governance. Environmental Communication: A Journal of Nature and Culture 6 (3): 346-364.

Tipa, Gail. 2009. Exploring Indigenous Understandings of River Dynamics and River Flows: A Case from New Zealand. Environmental Communication: A Journal of Nature and Culture 3 (1): 95-120.

United Nations Permanent Forum on Indigenous Issues (n.d.). Who Are Indigenous Peoples? Accessed October 26, 2014.http://www.un.org/esa/socdev/unpfii/documents/5session_factsheet1.pdf.

Walker, Gordon. 2009. Beyond Distribution and Proximity: Exploring the Multiple Spatialities of Environmental Justice. Antipode 41 (4): 614-636.

Watt-Cloutier, Sheila. 2004. Climate Change and Human Rights. Carnegie Council for Ethics in International Affairs. Accessed October 26, 2014. http://www.carnegiecouncil.org/publications/archive/dialogue/2_11/section_1/4445.html.

Westra, Laura. 2007. Environmental Justice and the Rights of Indigenous Peoples: International and Domestic Law Perspectives. London: Earthscan Publishers.

Winter-Jörgensen, Marianne and Louise Phillips. 2002. Discourse Analysis as Theory and Method. London: Sage.

Young, Iris. 2011. Responsibility for Justice. Oxford: Oxford University Press.

Ytterstad, Andreas and Adrienne Russell. 2012. Pessimism of the Intellect and Optimism of the Will: A Gramscian Analysis of Climate Justice in Summit Coverage. In Media Meets Climate: The Global Challenge for Journalism, edited by Elisabeth Eide and Risto Kunelius, 247-262. Gothenburg: Nordicom.

\section{About the Authors}

\section{Anna Roosvall}

is Associate Professor of Media and Communication Studies in the Department of Media Studies at Stockholm University, Sweden. Her research is centred on online journalism and issues of justice and solidarity, particularly in relation to identity politics, ethnicity, nationality and globalization. Her publications include Communicating the Nation: National Topographies of Global Media Landscapes (coedited with Inka Salovaara, Nordicom 2010), "The Identity Politics of World News" in International Journal of Cultural Studies (2014), and "Beyond Dialogue: Exploring Solidarity as Mode of Communication through a Debate on Readers' Comments to Online News" in Northern Lights (2014). Roosvall is part of the research network MediaClimate. Visit: https://su-se.academia.edu/AnnaRoosvall.

\section{Matthew Tegelberg}

is an Assistant Professor in the Department of Social Science at York University, Canada. His research on cultural tourism, media representations of indigenous peoples and environmental communication has appeared in Tourist Studies, International Journal of Cultural Studies, International Communication Gazette and in several edited collections. His current work places emphasis on the impact new media technologies and practices are having in these areas of study. Tegelberg is part of the research network MediaClimate. Visit: https://yorku.academia.edu/MatthewTegelberg. 